\title{
CITOMORFOLOGIA DO LÍQUIDO CEFALORRAQUEANO DO RECÉM-NASCIDO NORMAL
}

\author{
J. A. Livramento * \\ BERTHA R. DA LUZ ** \\ S. R. HAUSSEN ** \\ A. SpINA-França ***
}

São escassas as publicações sobre o líquido cefalorraqueano (LCR) do recém-nascido normal que tratam do exame citológico diferencial. Um dos poucos grupos de pesquisadores que cuidou do assunto é aquele de Reis ? Condições especiais levaram a que um de nós (BRL) obtivesse amostras de LCR de 79 recém-nascidos (RN) normais. A conceituação da normalidade desses RN baseava-se em: gestação normal; parto normal; peso, altura e perímetro cefálico normais (respectivamente: $3.213 \mathrm{~g} ; 49,24 \mathrm{~cm}$ e $33,51 \mathrm{~cm}$, em média); teste de Apgar aos 5 minutos de vida variando de 7 a 10 ; evolução até $8^{\circ}$ dia de vida sem intercorrências. Nos $79 \mathrm{RN}$ foi colhida amostra de LCR mediante punção lombar no segundo dia de vida; no sétimo dia de vida foi colhida nova amostra em 40 deles. As amostras de LCR foram analisadas e os resultados obtidos permitiram caracterizar os achados habituais ao LCR nessa faixa etária quanto a citologia global, concentração de proteínas totais e de bilirrubinas. O tratamento estatístico do material para intervalo de confiança de $95 \%$ permitiu verificar que o LCR do RN normal: contém até 12 leucócitos e até 600 hemácias por $\mathrm{mm}^{3}$; apresenta concentração proteica entre 23 e $120 \mathrm{mg}$ por $100 \mathrm{ml}$ e concentração de bilirrubinas não superior a 2,3 micromol/litro. A concentração desta última constituiu o motivo básico da investigação ( $\operatorname{Luz}^{5}$ ).

Os novos conhecimentos quanto aos tipos de células encontradas no LCR, resultantes do emprego de métodos de preparação que diminuem o risco de dano celular levou a que em certo número de amostras dessa casuística fosse estudada a citologia diferencial, isto é, o perfil citológico. $O$ objeto desta publicação é registrar os resultados desse estudo.

\section{MATERIAL E METODOS}

Foi estudado o perfil citológico do LCR lombar de 21 dos RN normais acima citados: 17 em que a amostra foi colhida no segundo dia de vida e 4 em que foi colhida no sétimo. Não foi estudada mais que uma amostra do mesmo caso. A

Trabalho do Centro de Investigações em Neurologia da Clínica Neurológica da Faculdade de Medicina da Universidade de São Paulo (Prof. H. M. Canelas): * Médico-adido; ** Médico-estagiário; *** Docente-livre. 
identificação obedece à ordenação adotada por Luz ${ }^{5}$, em função de cujos dados é assinalada também a contagem global de leucócitos e hemácias do LCR, para aproximação de dois algarismos (quadro 1 ).

\begin{tabular}{|c|c|c|c|c|c|c|c|c|}
\hline Caso & Ident. & $\begin{array}{l}\text { Leuc. } \\
/ \mathrm{mm}^{3}\end{array}$ & $\begin{array}{l}\text { Hem. } \\
/ \mathrm{mm}^{3}\end{array}$ & $\begin{array}{l}\mathrm{L} \\
\%\end{array}$ & $\begin{array}{c}\mathrm{RM} \\
\%\end{array}$ & $\begin{array}{l}\mathrm{N} \\
\%\end{array}$ & $\begin{array}{l}\mathrm{E} \\
\%\end{array}$ & $\underset{\%}{\mathrm{MF}}$ \\
\hline 1 & 1 & 7,3 & 8 & 18 & 73 & 8 & 0 & 1 \\
\hline 2 & 21 & 6,7 & 3 & 59 & 41 & 0 & 0 & 0 \\
\hline $\mathbf{3}$ & 22 & 8,0 & 260 & 36 & 54 & 4 & 2 & 4 \\
\hline 4 & 23 & 4,0 & 10 & 40 & 52 & 2 & 0 & 6 \\
\hline 5 & 24 & 2,3 & 90 & 35 & 59 & 3 & 0 & 3 \\
\hline 6 & 28 & 1,0 & 280 & 45 & 49 & 2 & 0 & 4 \\
\hline 7 & 30 & 1,0 & 11 & 48 & 52 & $\overline{0}$ & 0 & 0 \\
\hline 8 & 31 & 11,0 & 140 & 28 & 70 & 2 & 0 & 0 \\
\hline 9 & 32 & 5,3 & 11 & 35 & 53 & 2 & 0 & 10 \\
\hline 10 & 41 & 5,0 & 2 & 22 & 75 & 1 & 0 & 2 \\
\hline 11 & 42 & 4,0 & 320 & 11 & 70 & 17 & 1 & 1 \\
\hline 12 & 43 & 5,0 & 130 & 41 & 58 & 0 & 0 & 1 \\
\hline 13 & 44 & 4,0 & 140 & 26 & 69 & 2 & 0 & 3 \\
\hline 14 & 49 & 6,3 & 400 & 18 & 78 & 4 & 0 & 0 \\
\hline 15 & 51 & 7,0 & 540 & 40 & 51 & 8 & 1 & 0 \\
\hline 16 & 77 & 7,3 & 11 & 27 & 70 & 0 & 0 & 3 \\
\hline 17 & 79 & 4,3 & 4 & 27 & 73 & 0 & 0 & 0 \\
\hline 18 & 4 & 6,3 & 3 & 54 & 46 & 0 & 0 & 0 \\
\hline 19 & 5 & 4,7 & 1 & 38 & 60 & 0 & 0 & 2 \\
\hline 20 & 7 & 6,7 & 6 & 41 & 59 & 0 & 0 & 0 \\
\hline 21 & 9 & 7,7 & 57 & 38 & 56 & 6 & 0 & 0 \\
\hline
\end{tabular}

Quadro 1 - Identificação e citologia do LCR dos RN estudados. Legenda: Leuc. leucocitos; Hem. = hemácias; $L=$ linfocitos; $R M=$ reticulomonocitos; $N=$ polinucleares neutrófilos; $E=$ células eosinófilas; $M F=$ macrófagos. Na coluna Ident. (Identificacão) constam os números dos casos conforme figuram na tese de Berta $R$. da $\mathrm{Luz}^{5}$.

A preparação das amostras de LCR visando ao exame citológico específico foi feita mediante sedimentação gravitacional acelerada, empregando a câmara de Suta. A metodologia respectiva e a coloracão ulterior do preparado foi detalhada anteriormente ${ }^{8}$. O perfil citológico é referido em percentual segundo caracterização e classificação já analisadas ${ }^{9}$.

\section{RESULTADOS}

Constam do quadro 1 os perfis citológicos encontrados no LCR dos 21 RN estudados. Além dos tipos celulares nele referidos foram encontradas células que, por seus caracteres morfológicos, poderiam ser consideradas como próprias aos plexos corióides (CC) e como células reticulares indiferenciadas (RI).

CC foram observadas em 3 preparações (casos 8, 9 e 15) formando agrupamentos com disposição de tipo epitelial. Células isoladas semelhantes às que constituíam tais agrupamentos foram observadas eventualmente nesses mesmos casos.

RI foram encontradas em 5 preparações (casos 4, 9, 12, 13, 15), formando agrupamentos polimorfos mas não lineares e dos quais participava número variável de células. 
O contingente de RI e de CC foi pequeno em todos os casos. Sua ocorrência eventual e o fato de formarem agrupamentos levaram a que seu número não tivesse integrado o perfil citológico de cada caso.

Os caracteres morfológicos dos macrófagos (MF) permitiram identificá-los como de tipo hemossiderófilo e/ou hemático, na maioria dos casos. Pequenos agrupados de MF foram observados eventualmente.

\section{COMENTARIOS}

A perda minima de células, sua disposição em área restrita do suporte e a sua preservação melhor possível são alguns dos requisitos a ser obedecidos quando da avaliação de método de preparação das células do LCR para estudo citomorfológico, isto é, do perfil citológico. Esses requisitos são apontados por Krentz \& Dyken ${ }^{4}$ ao avaliar variante da técnica da sedimentação gravitacional acelerada de Sayk e, segundo eles, esta é atualmente a técnica mais adequada ao estudo da citomorfologia do LCR. A variante de Suta desse mesmo método reúne esses requisitos. É possivel, frente aos resultaods que fornece, reunir em classes de $\mathrm{I}$ a $\mathrm{V}$ a citomorfologia do $\mathrm{LCR}^{9}$.

No LCR normal do adulto são encontrados apenas linfocitos e reticulomonocitos (citomorfologia classe I). No recém-nascido são referidos polinucleares neutrófilos, células eosinófilas e macrófagos, além dos linfocitos e reticulomonocitos (citomorfologia classe II). Todavia, estudos sobre a citomorfologia do LCR do RN são eventuais na literatura: revisões e investigações sobre o assunto deixam a questão em aberto ${ }^{1,2,3,10,11}$. Reis \& col. 7, a propósito de 6 RN cujas idades variavam de 1 a 10 dias, encontraram o seguinte perfil citológico: linfocitos $16 \%$; monocitos $76 \%$; polinucleares neutrófilos $6 \%$; células eosinófilas e basófilas até 1\%; macrófagos e células imaturas até $2 \%$.

$\mathrm{Na}$ série de RN estudada nesta investigação o perfil citológico classe I ocorreu em 4 (casos 7, 17, 18 e 20), nos demais era classe II. Nestes, os outros tipos de células que caracterizavam a citomorfologia do LCR eram: polinucleares neutrófilos em 13 casos; células eosinófilas em 3 casos; macrófagos em 12 casos; células do revestimento corióide em 3 casos; células reticulares indiferenciadas em 5 casos. O fato de estes dois últimos tipos de células se apresentarem em agrupamentos lineares (CC) ou polimorfos (RI) poderia possibilitar a classificação desses casos na classe III : por não ocorrerem no LCR normal do adulto e pelo próprio fato de se apresentarem agrupados. Todavia, esta é uma peculiaridade do LCR do RN, considerando a relativa freqüência de sua observação, é preferivel manter esses casos como classe II, evitando possiveis confusões com células realmente atípicas.

A incompleta maturidade da barreira hêmato-liquórica no RN encontra, na presença de polinucleares neutrófilos, expressão do ponto de vista citomorfológico, embora estas células e eosinófilos possam advir do sangue drenado para o LCR em função do trajeto da cabeça no mecanismo de parto. O tipo principal de macrófagos encontrados permite relacioná-los à presença das hemácias ${ }^{6}$.

Não foram observados basófilos, como ocasionalmente é referido na literatura sobre o assunto ${ }^{\text {. }}$. 
Em conclusão, os resultados do estudo permitem assim caracterizar o perfil citológico do LCR do RN normal: presença constante de linfocitos e reticulomonocitos; presença comum de polinucleares neutrófilos e de macrófagos; presença eventual de células eosinófilas e de agrupamentos celulares. Estes são representados por células ependimárias, possivelmente do revestimento corióideo, e por células reticulares indiferenciadas, na possivel dependência da aracnóide. Em média, o perfil citológico do LCR dos RN estudados é representado pelas seguintes percentagens: linfocitos 34,6 ; reticulomonocitos 60,4 ; polinucleares neutrófilos 2,9 ; células eosinófilas 0,2 ; macrófagos 1,9. As variações encontradas em torno desses valores médios são grandes: para linfocitos, de 11 a $59 \%$; para reticulomonocitos, de 41 a $78 \%$; para polinucleares neutrófilos, de 0 a $17 \%$; para células eosinófilas, de 0 a $2 \%$; para macrófagos, de 0 a $10 \%$.

\section{RESUMO}

Foi estudado o perfil citológico do LCR de 21 recém-nascidos normais com 2 ou 7 dias de idade, os preparados tendo sido obtidos mediante sedimentação gravitacional acelerada. Para citometria normal (até 12 leuecocitos e até 600 hemácias por $\mathrm{mm}^{3}$ ), o perfil citológico era constituído de: linfocitos (11 a 59\%), reticulomonocitos (41 a 78\%), polinucleares neutrófilos (0 a $17 \%)$, células eosinófilas $(0$ a $2 \%)$; macrófagos $(0$ a $10 \%)$. Em média, as seguintes percentagens representam o perfil: linfocitos 34,6 ; reticulomonocitos 60,4 ; polinucleares neutrófilos 2,9 ; células eosinófilas 0,2 ; macrófagos 1,9. Podem ser observados também agrupamentos celulares: de células ependimárias possivelmente do revestimento corióideo; de células reticulares indiferenciadas, possivelmente da aracnóide.

\section{SUMMARY}

\section{Cerebrospinal fluid cytomorphology in the normal newborn infant}

Total cell count of cerebrospinal fluid (CSF) in normal newborn infants has shown no more than 12 leucocytes and 600 red cells by cubic millimeter, as it was previously reported by one of us ${ }^{5}$. Results on CSF cytomorphology are reported in this study.

CSF cytomorphology was studied in 21 normal newborn infants: 2 days old (17 cases) and 7 days old (4 cases). The samples were collected through lumbar puncture. Cytomorphological examinations were carried out after preparing the samples by accelerated gravitational sedimentation in Suta's chamber; the sediments were stained by Leishman's technique.

Cytomorphology was type II in most of the cases. Lymphocytes and reticulomonocytes were found in all cases, the relative proportion being $11-59 \%$ and $41-78 \%$ respectively. Polinuclear neutrophils were found in 12 cases, and the higher relative proportion observed for them was 17\%. Eosinophil cells occurred in 3 cases, in the proportion of no more than $2 \%$. Macrophages occured in 12 cases, and the higher proportion observed was $10 \%$. 
The average values were: lymphocytes $34,6 \%$, reticulomonocytes $60.4 \%$, polinuclear neutrophils $2.9 \%$, eosinophil cells $0.2 \%$, macrophages $1.9 \%$. Linear cell groupings occurred in 3 cases; their nature was morphologically related to choroid cells. Polymorph groupings of undiferenciated reticular cells were found also. They occurred in 5 cases, and their origin was related to cells of arachnoid membrane.

\section{REFERENCIAS}

1. DIAMENT, A. J. - O liquido cefalorraqueano do recém-nascido. Pediatria Prática (São Paulo): 35: 27, 1964.

2. DINIZ, H. B. - Determinação da idade da criança em que o líquido cefalorraqueano atinge o padrão de normalidade do adulto. Maternidade e Infância (São Paulo) 16: 291, 1957.

3. GYLLENSWARD, A. \& MALMSTROM, S. - The cerebrospinal fluid in immature infants. Acta Paediat. (Uppsala) 51 (suppl. 135):54, 1962.

4. KRENTZ, M. J. \& DYKEN, P. R. - Cerebrospinal fluid cytomorphology. Arch. Neurol. (Chicago) 26: 253, 1972.

5. LUZ, BERTHA R. DA - Contribuição para o Estudo da Xantocromia do Líquido Cefalorraqueano de Recém-Nascidos Normais. Tese. Fac. Medicina, Univ. de São Paulo, São Paulo, 1972.

6. RAUTENBACH, M. \& STEINIGER, U. - Das Liquorzellbild Frü-und Neugeborener bei Subarachnoidalblutungen. Mschr. Kinderheilk. 114:54, 1966.

7. REIS, J. B. DOS; DINIZ, H. B. \& WOISKI, J. R. -- Conceito de normalidade do lfquido cefalorraqueano no primeiro ano de vida. O Hospital (Rio de Janeiro) 78: $1457,1970$.

8. SPINA-FRANÇA, A. - Câmaras de sedimentação no estudo citológico do líquido cefalorraqueano. Arq. Neuro-Psiquiat. (São Paulo) 28:84, 1970.

9. SPINA-FRANÇA, A.; MACHADO, A. B. B. \& PASQUALIN, J. R. - Técnica de Suta e identificação de células neoplásticas no líquido cefalorraqueano. Arq. Neuro-Psiquiat. (São Paulo) 29:463, 1971.

10. WOISKI, J. R.; REIS, J. B. DOS \& BARROS, H. E. V. - Liquido cefalorraquiano do recém-nascido. Conceito de normalidade. Arq. Neuro-Psiquiat. (São Paulo) $7: 264,1949$.

11. WOLF, H. \& HOEPFFNER, L. - The cerebrospinal fluid in the newborn and premature infant. World Neurol. 2:871, 1961.

Centro de Investigaçōes em Neurologia - Faculdade de Medicina, Universidade de São Paulo - Caixa Postal 5199 - 01000 São Paulo, SP - Brasil. 